\title{
Determination of the Perceptions of Primary School Students Regarding the Concept of Television
}

\author{
Sevim Güven \\ Correspondence: Sevim Güven, Assist. Prof. Dr., Department of Primary Education, Faculty of Education \\ Gaziosmanpasa University, Turkey.
}

Received: June 14, 2017

doi:10.11114/jets.v5i8.2554
Accepted: July 24, 2017 Online Published: July 27, 2017

URL: https://doi.org/10.11114/jets.v5i8.2554

\begin{abstract}
Main purpose of the study is to determine how television is perceived by primary school students by means of metaphors and statements in figures. Being designed as a qualitative study, this study was handled in phenomenology patter and axis. The study was conducted with participation of 57 students continuing their education in 3rd and 4th grade in May 2016. In formation of the study group, analogous sampling technique as one of the purposeful sampling methods was used. The study data were obtained by means of "document analysis" from qualitative research data collection methods. With the purpose of revealing mental images relating to television concepts, the primary school students participating into the study were given an A4 paper with the sentence "Television is like ..., because ..." to complete on one side, and they were requested to draw a picture about meaning of television concept for the students, and answer the question "What do you want to explain in this picture?" Class teachers provided help for this procedure. The data obtained at the end of the study were analyzed with descriptive analysis and semiological analysis. 57 primary school students participating into the study developed 45 different metaphors and drew 57 different pictures. It was observed as a result of the study that primary school students had more intense positive perceptions towards televisions in their metaphors, and they defined television as mostly a free time and amusement tool. In pictures drawn relating to television, it was detected that television is mostly in the centers of settlement and they mostly used iconic indication and symbol.
\end{abstract}

Keywords: primary school, mass communication, media education, television, metaphor, semiology

\section{Introduction}

\subsection{Children and Television}

Mass communication has become the most important component of contemporary societies. This has profoundly increased the impact of mass communication tools on our lives. In comparison to interpersonal communication, mass communication is addressed to a broad, distinct and anonymous mass of people through tools such as books, magazines, newspapers, television and the internet and is generally thought of as a one-way flow of information (Boz, 1999). In the age of globalization, media organizations and services are controlled by market forces. These media organizations spread global culture in an age of technological revolution (Guru, Nabi \&Raslana, 2013). The media, which now have the power to influence social decisions and behaviors, can sometimes play a key part in people's decisions or protest actions occurring as a result of social upheavals ((Mizruchi, 2010). People monitor the media constantly in order to become aware of daily events and social developments and to develop a 'correct' opinion, as well as to pass time and be entertained and this naturally affects people's intellectual worlds, their decisions and behavior (Squires, 2012).

It is clear that one of the most important mass communication tools of the last century was television. Television is now an important device for most people, as most information is available to the public through this technology and it can easily deliver via cable or satellite any kind of information that consumers need to evaluate the contemporary world (Jusoff \& Sahimi, 2009). Compared to other mass communication tools, television remains predominant is constantly renewed through technological developments and clearly satisfies people's needs (Büyükbaykal, 2007). As the most common mass communication tool, television provides people with visual and auditory stimuli, and also offers them insight into a number of different settings and situations, both real and imaginary. As a consequence, it serves as a window onto the world outside, and is often found at the center of people's homes (Yapic1, 2006). Television has become such an accepted and influential power in society that it can shape the perception of the masses with regard to 
subjects as diverse as what to eat, what to wear, religion, law, education, sports, entertainment and marriage. Even people's homes are sometimes designed and organized around television.

A television is now an inseparable part of domestic furniture, and as there is at least one television in each house, children grow up in a world with television from the beginning of their lives; they start to watch television from the age of 2-3 (Gunter \& McAleer, 1997). Twenty-first century adults and young people spend a lot of time in front of the television, and, in addition, their internet use and the time spent playing video games are also high (Aksaçlığlu \& Yılmaz, 2007; Aral \& Aktaş, 2007). Today, along with the family, school and the environment, television is one of the most important components in the socialization of children (Kaya \& Tuna, 2008). Television is consumed by children in three ways: "passion television" consists of programs enjoyed and watched through a conscious choice at a specific time, "property television" is television watched when studying or having breakfast/eating, and "gap-filling television" is watched when children have nothing better to do (Ișık, Erdem, Güllüoğlu, \& Akbaba, 2007). Television audiences are motivated to watch television in order to satisfy their wishes, needs and desires; however, this watching television does not occur as a result of strong psychological drivers at all times, but only at specific times, although young people also do, to some extent, watch for a reason. This reason may be as simple as "passing time" (Gunter \& McAleer, 1997). It has been revealed in some studies that as well as the programs themselves, commercials also have an effect in the formation of a number of habits (Larson, 2003; Hestroni, 2011; Pine \& Nash, 2002).

The early penetration of television into our lives has been shown to have disadvantages, particularly in the early part of childhood, despite also having some advantages. A number of studies relating to the relationship between television and violence reveal this situation (Mutlu, 1997; Larson, 2003). It has been stated that there is far more violence in children's programs than in other television programs in general. Two experiments conducted by Lull (1988, cited by Mutlu, 1997) revealed the effect of television. In the first experiment, a family was given some money and asked not to watch television; however, after a while the family gave up the money and turned on the television. In the second experiment, it was observed that a family whose television was broken had communication problems that did not exist previously, and after the arrival of a new television, these problems were eliminated. This reveals the truth about television in our lives. Thus, all parts of society should be conscious when watching television. Television has powerful effects on children. TV gives positive messages to children but it also can cause children to be inactive and prevent creative play. The use of all mass media, not just television, should be monitored, because, as studies reveal, mass communication tools can have both physically and mentally negative effects on children. According to a survey of four-year-old children, television makes no positive contribution to learning at school. Adult TV programs are harmful to the development of children (Barr, Lauricella, Zack, \& Calvert, 2010). However, according to another study, "Children can develop their behaviors observed through positive social programs they watch because they mimic the behaviors they see on the screen (Christakis, Garrison, Herrenkohl, Haggerty, Rivara, Zhou, \& Liekweg, 2013). Lillard \& Peterson (2011) found that TV had a negative effect on children's executive functioning when they were working with children aged four. Children are afraid of watching programs related to disastrous events and social problems on television and the internet. These fears can lead to problems with regard to children's sleeping, eating and relieving themselves, in being able to play and function in social environments, in showing more aggressive behavior, or in becoming more uncomfortable with others (Catron and Allen 2008). Television is one of the mass media tools which affects the behaviors of children, and is also the one which has the most effect (Santrock, 2011).

Too much television is watched in Turkish society. Watching television has become almost the only form of entertainment and tool for receiving information for people living in Turkey. Research shows that television addiction in Turkey is also higher than might be expected. The 2015 "Guide to Understanding Turkey" based on research conducted by Ipsos KMG every two years clearly shows how much television is watched in Turkey. According to the research, almost everyone living in Turkey watches TV every day. $84 \%$ of those surveyed said they watched television every day ("Television is watched unceasingly in Turkey" 2015). A survey conducted by the Turkish Statistical Institute, showed that Turkish people watch TV for 6 hours a day (in the country as a whole and as an average) spend 3 hours on the internet and only 1 minute reading a book. Reading books ranks 235th on Turkish people's lists of need (Uras, 2016). According to another study, Turkey has broken the world record in daily television watching, with an average rate of 330 minutes per day ("Turkey broke the world record in television watching", 2017). Although its role in socialization is known, a child interacting with television for any reason starts to become immediately affected and can become addicted to watching television with time. In a study conducted on the television watching behaviors of children in 2013 by the Turkish Radio and Television Corporation (TRTC), it was found that $20 \%$ of our society watched television for 5 hours a day. The "Time periods when television is watched in general during the week" by students participating in the study were "18.00-21.00" with a ratio of 53.1\%, "21.00-24.00" with a ratio of $25 \%$ and " $15.00-18.00$ " with a ratio of $24 \%$. It was observed that "primary school" students watched television more often in early hours of the day, while "high school" students watched television more often between "21.00-00.00" and "00.00-03.00". 
In addition to the possibilities provided by the media, the growing diversity of the media and the power to influence individuals at all ages demonstrates the concept of media literacy. Media literacy is basically defined as the ability to receive, analyze, evaluate messages which have been transmitted via large formats (Hobss, 1998). With the development of technology, the electronic media attracts children and adults through the extraordinary techniques and channels used, and children in particular may be overwhelmed by this bombardment of information if they do not filter the materials presented to them (Treske, 2011). Media literacy prevents this. The use of media literacy to combat the influence of media, especially television, has been seen as a necessity and perhaps a solution to the problems caused, and at the same time, the provision of media literacy education in schools is being debated (Erdoğan, Uysal, Altın \& Saki, 2015). Media literacy courses have been provided in education in Turkey beginning from the 2007-2008 academic year. However, media literacy training in Turkey has not yet become fully widespread and has not yet created an effective awareness of the media. Even though education has started to be provided for primary school students, the education of parents is very inadequate (Gündüz Kalan, 2010).

\subsection{Children's Drawings}

Perceptions demonstrate an awareness of something sensed (Ersoy \& Türkkan, 2009). For a child, one of the best ways to show perceptions and make sense of her/his environment is through pictures. In all their dimensions, pictures drawn by children are a reflection of the world as perceived and a collection of different experiences and thoughts. It has been stated that, in drawing pictures, children spontaneously manifest their inner world and without resistance in a form perceived as play and that they communicate information relating to their inner world (Kayacan Keser \& Eren, 2015). The child does not want to orally express intense emotional issues or thoughts about her/his family, her/himself and her/his friends. Through art, however, these emotions, thoughts, fears and disappointments can be expressed (Schirrmacher 2001). Yavuzer (2012) separates the developmental stages of children's picture into the "scribbling stage" (ages 2-4), "pre-schematic stage" (ages 4-7), "schematic period" (ages 7-9), "reality (gang period) period" (ages 9-12), "apparent naturalism stage" (ages 12-14). "A child expresses himself/herself better with pictures. It becomes easier to perceive abstract concepts. It becomes possible to recognize children who have trouble in establishing verbal communication and to teach them properly" (Savaş, 2014. p. 26). "The figures which cause emotional reactions during children's artistic activities indicate, in artistic form, the facts of what they have seen, heard, known, touched and perceived" (Yurtal \& Artut, 2008, p. 150). Children explain the characteristics of the environment they live in and perceive through images, and they also demonstrate their perceptions of their emotions and intellectual lives through symbols in their drawings (Kayacan Keser \& Eren, 2015). Children's pictures open windows into the mental world of a child. Each drawing is the beginning of a journey; at the end explanations relating to personality of the child and purposes of her/his behavior can be formulated. Children's drawings and handwriting helps us understand what they are experiencing, and provides opportunity to find exact answers for questions about their activities and to questions occupying the parents (Wimmer, 2014). There are a number of approaches relating to why a child draws pictures:

The developmental approach ('drawing as a play') regards the drawings of a child as a play; the projective approach handles pictures as reflections of clinical conditions; the artistic approach evaluates drawings artistically within a developmental process; the symbolic approach looks at the meanings contained in the specific images/figures in the pictures, in that it regards symbols and figures as a way of explaining thoughts and emotions (Savaş, 2014). In recent years, the number of studies on the meaning, diversity and psychological dimensions of children's pictures has increased (Bland, 2012; Erişte, 2010; Istomin, Panakova \& Heady, 2014; Sadık, Çakan \& Artut, 2011; Simon \& Stokes, 2015). This is a consequence of drawing being one of the most effective forms self-expression for children, because a picture is a projection of the emotion and thoughts of a child.

It is important to evaluate childrens' pictures with a symbolic approach and to look at messages in the picture in terms of semiology. "We can define semiology by the method it uses. Accordingly, semiology is a science which applies linguistic methods to objects, attempts to define everything (play, gestures, facial expressions, religious rites, literary works, audio recordings) through language and convert all non-linguistic facts into language metaphors" (Dervişcemaloğlu, 2005). Peirce (Özmakas, 2009) defines semiology into "primary, secondary and tertiary [forms], and also divides these into the indication, interpretant and object triplet. The concept of indication as the first component of these consists of triplets divided into three within itself. There are qualitative indication, singular indication and rule indication types in the first triplet; iconic indication, sign and symbol in the second triplet; and lexeme, suggestion and evidence indication in the third triplet...The concept of indication comprises a limitless field to contain all communication systems such as language, the morse alphabet, traffic signs, etc" (İnam, 2008). In this study, pictures were interpreted based on the object dimension as the third triplet. Iconic indication represents what the picture expresses directly; sign is the relationship with reference to sign existence; there is no similarity or connection between indication and object in symbol. The only reason for the use of symbols in the establishment of meaning is the common view of people about what a symbol is being substituted for and what it describes (Yilmaz \& Temizkan, 2013). Because 
pictures drawn by children may reflect their inner worlds symbolically, they are analyzable in semiological terms and can provide detailed hints about children's development and perceptions. For example, the position and distance from the viewer of an object drawn by a child and the dimension of pictures may be important (Türkcan, 2013).

\subsection{Metaphor}

Metaphor is one of the most powerful mental processes that forms, directs and controls our thoughts about the formation and operation of events (Saban, 2004). Lakoff and Johnson (2010) state that metaphor is not only a language issue, but that the process of thinking itself is metaphorical. According to Erdoğan and Erdoğan (2012), metaphors are cognitive tools that we used to conceptualize words or thoughts, and at the same time they are powerful tools used by people to explain abstract concepts and high-level, complicated truths. Metaphor is understanding one situation and concept using another situation or concept and interpreting it accordingly. For many people, metaphor is a tool for poetic language and imagination, a perfect technique for teaching what is unknown, and a proven tool for storing and remembering learnt information (Arslan \& Bayrakçı, 2006). Metaphor may be used for facilitating comprehension by making an abstract concept material (Singh, 2010). In brief, the core of metaphor is to understand and experience one thing with respect to something else (Lakoff and Johnson, 2010). Metaphor may be also said to be the art of relating our emotions, thoughts and beliefs with fewer words. Metaphors can be used to redefine facts and encourage conceptualization of problematic situations as they affect the ways in which situations and events are perceived (Goldstein, 2005).

In recent years, metaphors have frequently been used in educational studies in order to understand the presence of concepts in the minds of individuals through other words apparently unrelated to the concepts themselves, as the reflective and analytic approaches of school age children (ages 6-11) towards language enable them to comprehend more than one meaning of words (Güler, Akgün, Öcal \& Doruk, 2012). The ability to understand synonyms provides the opportunity for children aged 8-10 to comprehend non-literal meanings (Berk, 2013). "The increase in logical reasoning and analytical skills of children of primary school ages helps them to understand the proper use of structures such as making comparison and expressing personal ideas" (Santrock, 2011). Thus, the use of metaphor in daily language is related to the process of language development and the voluntary/involuntary interaction of the child with her/his environment.

Examining the related literature, it is seen that a number of studies have been conducted on various dimensions of television (Aral \& Aktaş, 1997; Chang, 2000; Küçükbasmac1, 2013; Larson, 2003; Hestroni, 2011; Pine \& Nash, 2002; Robinson, Winiewicz, Fuerch, Roemmich, \& Epstein, 2006); on student drawings (Arslan \& Bayrakçı, 2006; Bland, 2012; Coşgun, 2012; Dağlıoğlu, 2014; Dervişcemaloğlu 2005; Demir \& Ülkü, 2013; Erişti, 2010; Ersoy \& Türkkan, 2009; Simon \& Stoke, 2015; Güler \& et al., 2012; Rayt, Komulainen, Paajanen, Markkanen, Skorokhodova, \& Kolesnikov, 2012; Simşek İşliyen \& İşliyen, 2015; Wang, 2014) and on metaphor (İnam, 2008; Ergen \& Yanpar Yelken, 2015; Karaçanta, 2013; Saban, 2004; Singh, 2010; Szukala, 2011; Şentürk, 2009; Türkcan, 2013). However, only a limited number of studies have been conducted using pictures and metaphors to determine the perceptions of primary school students regarding the concept of television. Hence, it was necessary to conduct this study.

This study investigates how television as a form of popular culture is perceived by primary school students. To this end, the main purpose of the study was to determine how primary school students perceive television using metaphors and images. In line with this purpose, answers were sought to the following questions:

1. What are the most commonly used verbal metaphors among primary school students relating to the concept of television?

2. What types of signs are used by primary school students in pictures relating to the concept of television?

3. What are the icons, indices and symbols used in pictures by primary school children relating to the concept of television?

This study reveals how primary school students perceive television through consideration of their verbal metaphors and drawings.

\section{Method}

This section of the study includes information relating to the study model, population and sample of the study, the collection of data and data analysis.

\subsection{Study Model}

The data obtained by means of metaphor and by applying this to pictures drawn by children in educational environments were analyzed as literary and artistic data in accordance with current beliefs. Hence, this study, which aimed to reveal the perceptions of primary school students towards the concept of television was designed with a 
phenomenological method using a qualitative study approach. It is the purpose of the phenomenological method of study to reveal how an individual assign meaning to her/his life and perceptions (Eraslan, 2011).

\subsection{Study Group}

The participants were students in primary schools in a Turkish city. They consisted of third and fourth grade primary school students. The study was conducted with 57 students aged between 8 and 9 years old in continuing education, in the 3rd (f.19) and 4th (f.38) grade in May 2016. 27 of the students were female and 40 were male. The study group was formed by using the homogeneous sampling technique (Patton, 1987), which is one of the techniques of the purposeful sampling method. The reason of selecting participants from among primary school students is that profoundly qualitative data can be obtained in their use of metaphors regarding pictures to reflect their opinions relating to a subject. Children were reminded throughout the data collection activities that participation was voluntary.

\subsection{Data Collection}

The study data was collected using "document analysis", one of the qualitative study data collection methods. With the purpose of revealing their perceptions relating to television, the primary school students participating in the study were given an A4 paper with the sentence, "Television is like ..., because ..." to complete on one side, they were asked to draw a picture about the meaning of television, and answer the question "Can you explain in this picture?" Class teachers provided help during this procedure. Students were given 25 minutes for the task. Participation was voluntary.

\subsection{Data Analysis}

The data obtained at the end of the study were analyzed with descriptive analysis and semiological analysis. The 57 primary school students participating in the study developed 45 different metaphors and drew 57 different pictures. Papers which were left blank by 9 students and which did not provide proper data were not included in the study. Each participant was coded with a paper number, grade and gender (such as $1(4 . \mathrm{K}) ; 2(4 . \mathrm{E}) \ldots$..). The metaphors of the participating students were ranked by frequency $(f)$. In all analyses, all metaphors and classifications of metaphor were presented as tables. The pictures drawn by the children were analyzed semiologically. The data obtained for validity and reliability of the study data were examined by the researcher and an expert. The "icon, index, sign", triplet of Pierce was used in semiological analyses of the students' work. The students' opinions were applied to the analysis of the pictures drawn and elements within the pictures, and tables were again used in the analysis of the pictures. The frequency of the obtained data was determined. In the study, the metaphors given by the students relating to television and the pictures drawn were associated by comparing them with the categories and answers given by the students, and analysis was finalized.

In this study, validity and reliability were determined by using expert examination. In expert examination, information about the research methods, research process and findings is shared with people who are unbiased for their ideas and opinions (Krefting 1991). While analyzing the data, the researcher formulated categories and codes for children's drawings, metaphors and statements. These categories and codes were coded separately by the researcher and an expert and the consistency between the coders were examined and the reliability of the data analysis was tested by using Miles and Huberman (1994)'s formula of Agreement Percentage = [Agreement/ (Agreement + Disagreement) X 100]. Accordingly, the agreement percentage between the coders was determined as $88 \%$ for the drawing technique and $86 \%$ for statements.

\section{Results}

This section of the study incorporates the results obtained as a consequence of the evaluation of the data acquired from the metaphors used and the pictures drawn by the children.

1. Results relating to the sub-problem of which metaphors relating to television were most commonly used by primary school students are provided below.

It was seen that the 57 primary school students participating into the study developed a total of 40 metaphors relating to the concept of television. These metaphors were categorized as positive, negative and both positive and negative. The metaphors developed by the students are presented in Table 1 . 
Table 1. Metaphors relating to television

\begin{tabular}{llll}
\hline Positive metaphors & f & Negative metaphors & f \\
\hline A friend & 6 & An enemy & 4 \\
An entertainment tool & 3 & A bad thing & 1 \\
A dream and happiness & 2 & A brain-eater & 1 \\
A friend who provides information & 2 & A harmful machine & 1 \\
A nice garden & 2 & An unreal thing & 1 \\
Technology & 2 & Both a good and bad thing & 1 \\
A sibling & 2 & Disease & 1 \\
An information sign/source & 1 & A harmful object & 1 \\
Entertainment and information & 1 & A bad friend & 1 \\
An informative story & 1 & A disgusting thing & 1 \\
A friend if a real friend is absent & 1 & Both beneficial and harmful & 1 \\
Part of the family & 1 & Entertaining, funny but sometimes horrible & 1 \\
Life & 1 & A wizard, a thief, sometimes a book & 1 \\
Water & 1 & Both a good and a bad thing & 1 \\
A way of spending free time & 1 & Both a friend and an enemy & 1 \\
A smiling baby & 1 & A thing which changes people's emotions and & 1 \\
& & thoughts & \\
Love & 1 & & $\mathbf{1 8}$ \\
A book & 1 & & \\
Something cool & 1 & & \\
A happy party & 1 & & \\
Something good & 1 & & \\
Beauty & 1 & & \\
Something funny & 1 & & \\
A tool we need in life & 1 & & \\
Light & 1 & & \\
Total & $\mathbf{3 7}$ & Total & \\
\hline Presents metaphors & 1 & \\
\hline
\end{tabular}

Table 1 presents metaphors developed by primary school students relating to television. Examining the metaphors, it is seen that the students gave positive, negative and both positive and negative metaphors about television. However, there are more positive metaphors. On examination of metaphors, it is seen that television is generally seen as a form of entertainment in the students' opinions. The opinions of some participants about this subject are as follows: 2(4.K) interprets television as a source of information and a friend, explaining that "Television is like my friend, because television presents news, and explain what happens to people, so that television is a friend who gives me information 48(3.E) interprets television as a way of passing free time as well as a source of information, saying "I watch television when I am bored, because television provides new information to me." In another opinion, 4(3.K) says that television is "like a friend, because I watch when I am bored", while student 27(4.K) states, "In my opinion, television is like water, because television is a necessity, and water is a necessity. Time flows by like water when I watch television." With such an explanation, she views television as a basic necessity, and regards it as a way of spending time. Another student, 3(4.K), defines television as a form of entertainment, explaining that it is "like an entertainment device, because it entertains me when I am bored and do not read a book. Movies and television series in television entertain me." Examining the metaphors, as well as definitions as an entertainment and way of spending time, descriptions of negative aspects are also observed. Accordingly, 42(3.E) explains that television is " $a$ bad friend, because it deletes beneficial information in our brain," while 41(3.K) states that it is "a harmful object because we watch it 24 hours a day, and our brains may be damaged. We forget things we've remembered, as we watch it". 4(4.K) explains that it is both a good and a bad thing, and that our brain gets tired when we watch television. Its good aspect is that people are informed about the students. A student who finds television entertaining but sometimes a bad thing says the following: "[It is] like an enemy, because it emits radiation ... television is not always good. Television is sometimes like a bad dream. Television is a part of life" (30(3.E)). A student regarding television as both beneficial and harmful states: "In my opinion, television is a being that changes people's emotions and thoughts, because it is both beneficial and harmful. Programs we watch on television affect us, and lead us to different thoughts." This student thereby has an awareness of both aspects of television.

Moreover, television is seen as a tool for passing free time and to overcome boredom. The students' statements generally indicate this. For example: "I spend my free time in front of the television"; "I watch television when I am bored"; "If I am bored, I watch television"; "We spend time with television when we are bored"; "Television entertains me"; "I like television, I watch when I am bored"; "It makes me feel better when I am bored"; "It supports me and entertains me when I get bored". 
2. Results relating to the sub-problem of what types of signs relating to the concept of television are used in pictures by primary school students

Signs in pictures drawn by students relating to television are given below.

Table 2. Distribution of types of signs used

\begin{tabular}{ll}
\hline Signs Used & f \\
\hline Icons & 200 \\
Symbols & 53 \\
Indices & 24 \\
\hline $\mathbf{N}=\mathbf{5 7}$ & \\
\hline
\end{tabular}

As shown in Table 2, students mostly preferred to explain television with iconic signs in the pictures drawn. They mostly draw an image of what immediately comes to mind as denoting television. Symbols are the second commonly seen types of sign after iconic signs. Indices are the types least commonly used by the students.

3. Results relating to sub-problem of what icons, indices and symbols are found in primary school students' pictures relating to television.

Iconic signs determined in the pictures of the students are shown in Table 3.

Table 3. Iconic signs used by the students

\begin{tabular}{llll}
\hline Iconic signs & f & Iconic signs & f \\
\hline TV & 51 & Food and beverages & 2 \\
Child watching TV & 50 & Table & 2 \\
Armchair & 22 & Sword & 1 \\
TV Unit & 19 & Stream & 1 \\
Coffee table & 8 & Computer & 1 \\
Sun & 7 & Ambulance & 1 \\
Ball & 6 & Cabinet & 1 \\
Speaking ball & 6 & Police Vehicle & 1 \\
Car & 6 & Lightning & 1 \\
House & 5 & Lamp & 1 \\
Newsreader/Journalist & 4 & Stretcher & 1 \\
Rope & 3 & Coffee Cup & 1 \\
Chair & 3 & Beko Brand TV & 1 \\
Grass & 3 & Vestel Brand TV & 1 \\
Written news & 3 & Arçlik Brand TV & 1 \\
Cloud & 3 & Carpet & 1 \\
TRT Channel & 2 & Vase & 1 \\
Clock & 2 & & \\
\hline Total & & & $\mathbf{2 0 0}$ \\
\hline 3, prima che
\end{tabular}

As seen in Table 3, primary school students generally draw objects that directly denote "television". Examining pictures drawn by the students, it is seen that they most commonly used the iconic sign type. They most commonly draw a television or a child watching TV. For example, answers were given such as: "I watch television, I watch television happily." (34(4.E)); "I watch competitions, I watch everything." (35(4.E)); "The baby watching television is smiling." (36(4.E)); a child is watching television, he likes watching television." (24(4.E); "I wanted to explain that I have fun watching a match" (13(3.E). Some of the students' pictures are given below. 


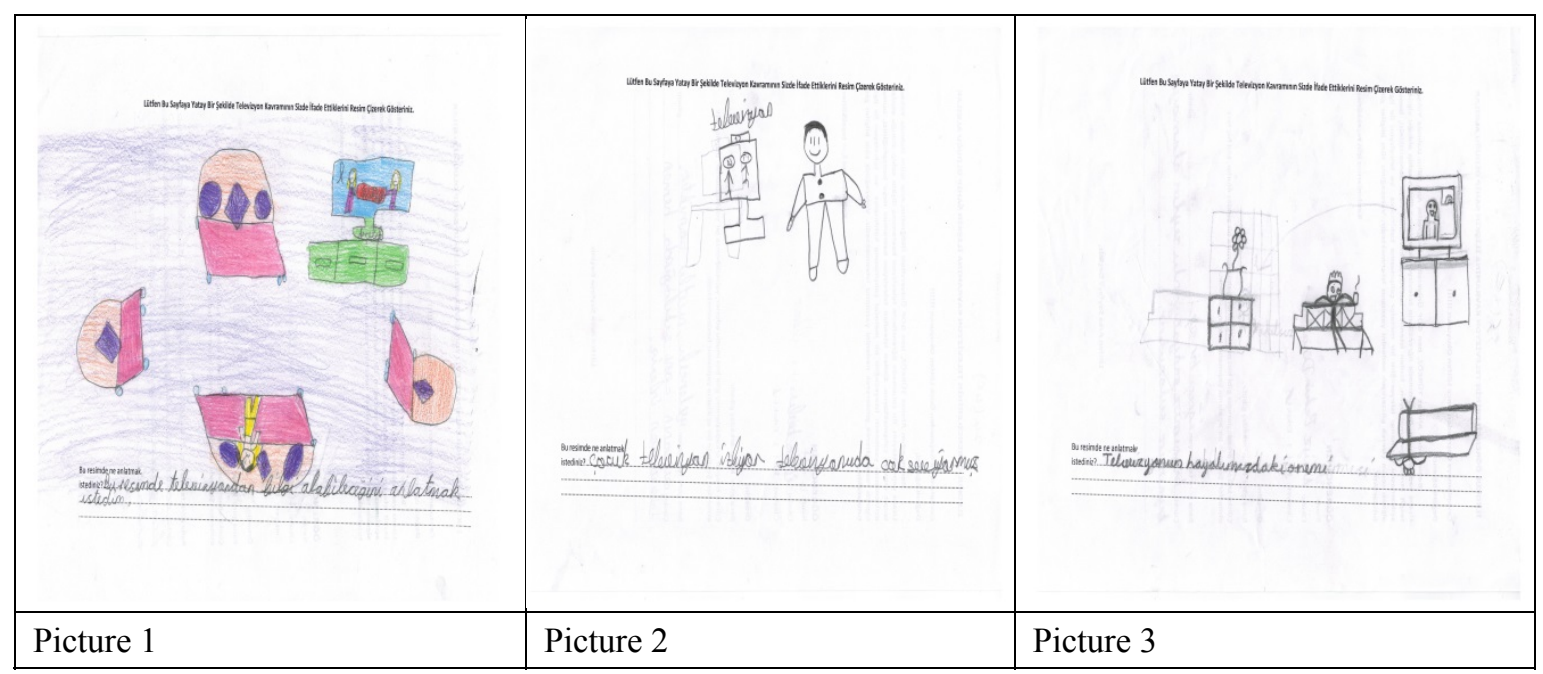

Symbols determined in the students' pictures are shown in Table 4.

Table 4. Symbols used by the students

\begin{tabular}{lll}
\hline Symbols & \multicolumn{1}{c}{ Meaning } & f \\
\hline Smiling Child Watching & Happiness & 26 \\
TV & Happiness & 6 \\
Flower & Sad & 4 \\
Sad Child Watching TV & Happiness, freedom & 2 \\
Bird & Angry & 2 \\
Angry Child Watching TV & Success, information & 2 \\
Book & Detection & 2 \\
Comparison of two pictures & Importance of nature & 2 \\
Nature & Damage to brain & 1 \\
Sleeping child & Happiness & 1 \\
Tree & Joy & 1 \\
Chocolate & Joy, love & 1 \\
Dog & Excitement & 1 \\
Sea & Happiness & 1 \\
Dolphin & Life is passing by/time is \\
Dead person & being wasted & 1 \\
\hline Total & & $\mathbf{5 3}$ \\
\hline
\end{tabular}

As seen in Table 4, all symbols drawn by the students implied another meaning. The symbols in Table 4 revealed as a result of analyses of students' pictures were handled in accordance with the idea that the object drawn had a symbolically different function. The most commonly used symbol was a child watching television. Using this symbol, the students associated watching television with happiness. The students used smiley faces in their pictures, and in their explanations regarding this issue, they identified a smiley face with happiness. For example, 27(4.K) states: "In this picture, a girl watches a man or a child and likes it."; 24(4.E) states: "The child is watching television, he likes television."; 25(4.E) states: "A family is watching a football match together."; 33(4.E) states: "A child is having fun watching a cartoon"; 46(3.E) states: "We have fun."; 49(3.E) states: "I have so much fun watching television." From among the students using a book as a symbol, 18(4.K) states: "I would prefer a book if I have to choose between television and a book"; 21(4.K) states: "Everyone should read books instead of watching television"; 56(3.K) states: "I wanted to explain in this picture that television affects our success." Child 4(4.K), drawing an angry child, states: "My brain gets tired when I watch television, the brain of this child in the picture is tired as well."; 7(4.K) states: "In the first picture we're watching a movie affecting our mental health negatively, and in the second picture, we're watching a documentary program affecting our mental health positively."; In a picture featuring death, 19(4.E) states: "In this picture, I wanted to explain that time is passing by quickly as we watch television." All the students thus communicated messages relating to their television preferences. Sample pictures relating to the issue are given below. 


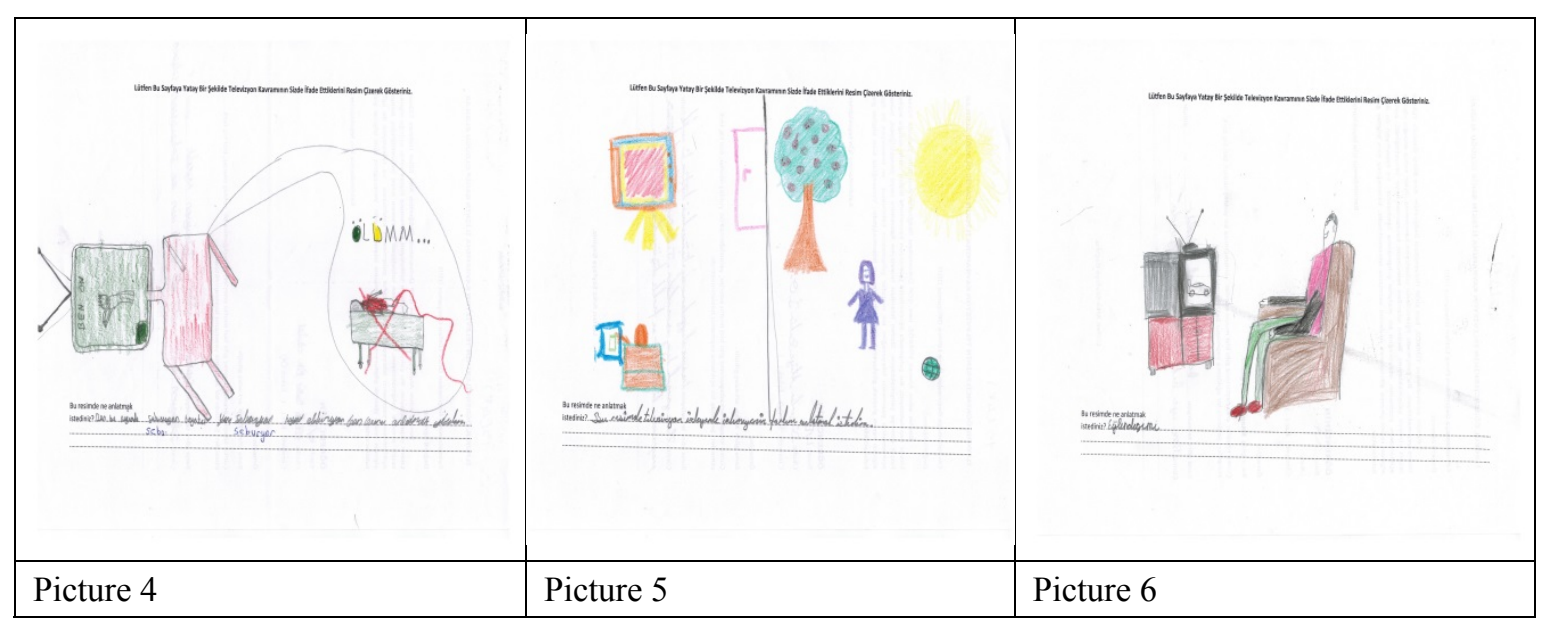

Indices determined in the students' are given in Table 5.

Table 5 . Indices used by the students

\begin{tabular}{llr}
\hline Index & Cause-effect relationship & f \\
\hline Antenna & TV Reception Status & 9 \\
TV Buttons & Switching TV On/Off & 6 \\
TV Remote Control & Switching TV On/Off & 5 \\
TV Wave & Radiation Effect & 3 \\
Microphone & Tool for Speaking Into & 1 \\
\hline Total & & $\mathbf{2 4}$ \\
\hline
\end{tabular}

As seen in Table 5 , the indices revealed from analyses conducted on pictures drawn by the students relating to television can be evaluated in terms of the cause-effect relationship the object drawn refers to. Some explanations of the students' pictures are as follows: 13(4.E): "Television emits radiation. I drew a picture explaining this"; 5(4.E): "Here a child is watching television and sleeping, the television is emitting radiation and makes it sick." Observing such situations, it may be said that the students' pictures reflect their experiences with television in daily life. Some sample pictures relating to the said results are given below.

\begin{tabular}{|l|l|l|}
\hline & \\
\hline Picture 7 & & Picture 9 \\
\hline
\end{tabular}


Table 6. Codes relating to students' explanations of their pictures

\begin{tabular}{ll}
\hline Codes & f \\
\hline Entertainment /happiness & 12 \\
Provision of information and news & 9 \\
Damage to eyes & 6 \\
Pleasure in playing games & 5 \\
Emission of radiation & 3 \\
Part of the family & 3 \\
Advertisement & 2 \\
Stimulates dreams & 2 \\
Damage to brain & 2 \\
Awareness of natural beauty & 2 \\
Benefits/hamr & 2 \\
Disruption of work & 2 \\
Waste of time & 2 \\
Trigger of violence & $\mathbf{5 6}$ \\
Negative effect on success & 1 \\
For decorative purposes & 1 \\
Disruption of mental health & 1 \\
Disruption of health & 1 \\
\hline Total & 1 \\
\hline codes relating to the explanations \\
\hline
\end{tabular}

Table 6 includes codes relating to the explanations given by the students relating to their pictures. It was observed that the children stated that television was for entertainment/happiness and the provision of information/news. It was concluded that the students regarded television as entertaining, and that they were also aware of its negative effects. 15(4.K) states: "A man [is] happy to watch television"; 16(4.E) states: "I wanted to explain in this picture that television is like a part of the family"; 34(4.E) states: "I watch television, I watch television happily"; 11(4.K) states positively: "I wanted to explain in this picture that we could learn what is going on in the world thanks to television"; while among the more negative opinions, $39(3 \mathrm{~K})$ states: "Watching television may harm your eyes"; 9(4.E) states: "I wanted to explain that there is both benefit and harm in watching television"; 8(4.K) states: "In this picture, I wanted to explain that children who watch television show irritable and aggressive behaviors, and that television disrupts the child's mind"; 4(4.K) states: "Generally my brain gets tired when I watch television, the brain of the child in the picture is tired as well"; 5(4.E) states: "The child here is watching television and sleeping, the television is emitting radiation and makes it sick". Sample pictures relating to this issue are given below.

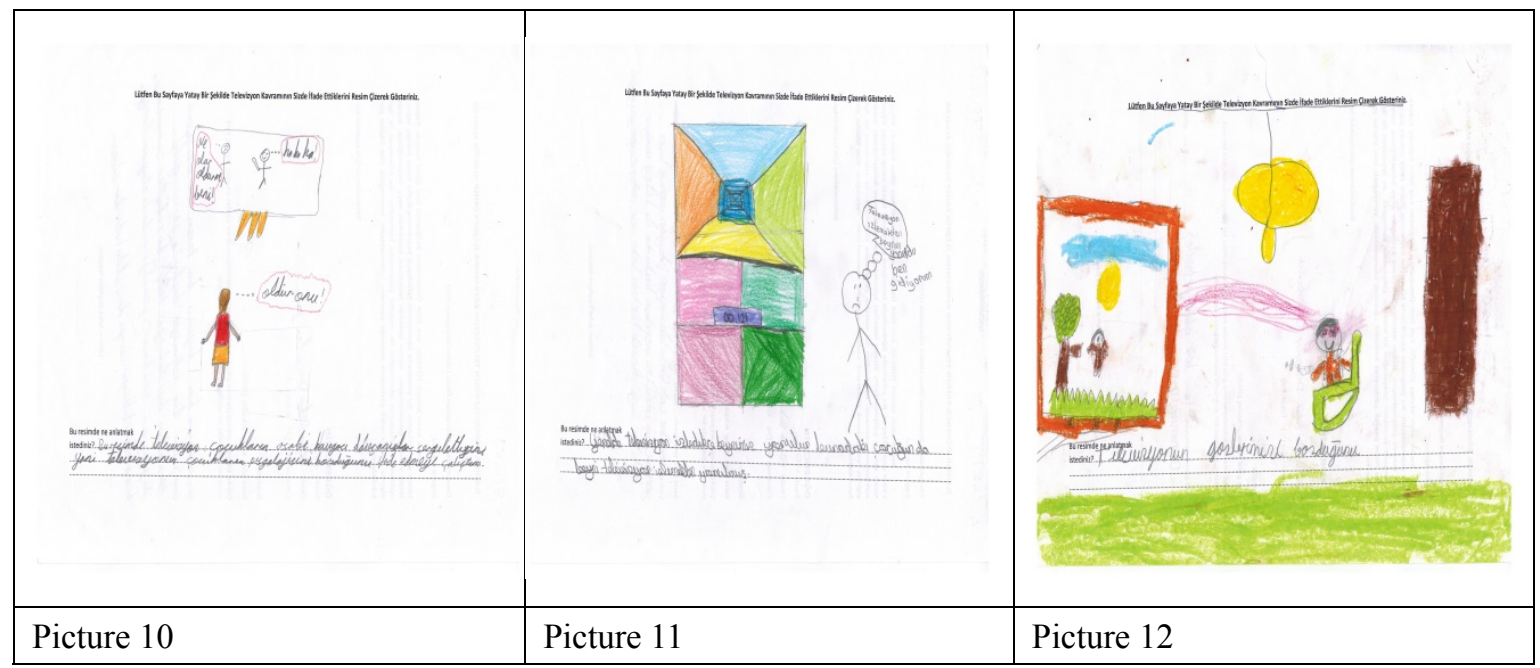




\section{Conclusion, Discussion and Suggestions}

Many studies have been conducted on the role of television in today's consumerist society. However, the role of television in society and its specific effect on children cannot be completely understood. Actually, the relationship of a child to the family, society and television during her/his socialization process is ambiguous (Carlson, Laczniak, \& Walsh 2001). Without doubt, television is one of the most common media tools. Children of school age spend a remarkable portion of their time in front of a television.

In this study, which aimed to reveal the perceptions of primary school students relating to television and to illuminate this issue if only to a small extent, it was seen that the participants associated television with many different concepts. Examining the metaphors used by the students participating into the study, it was concluded that they regarded television as a necessity, they characterized it as a friend, as an entertainment device and as harmful, and, in general, they had positive opinions relating to television. However, these primary school students also developed negative metaphors expressing negative attitudes and opinions relating to television. They mostly used the iconic signs which came to their minds immediately as denoting television. Symbols were the second most commonly seen types of sign after iconic indications. Indices were the types least used by the students.

To represent television, students most commonly drew the iconic image of a television or a child watching TV. The indices revealed as a result of analyses of the students' pictures indicated that cause-effect relationships were being ascribed to the object drawn. The symbol most commonly used by the primary school students was a child watching television. Using this symbol, they associated happiness with the child being happy while watching television. Codes relating to the students' explanations of their pictures were included. It was observed that the children gave statements involving entertainment/happiness and the provision of information/news. From the explanations, it was concluded that the students regarded television as entertaining but that they were aware of its negative effects as well.

It was concluded that primary school students generally had positive opinions relating to television, they enjoyed watching television and they regarded it as a form of entertainment. One of the main functions of television is to provide information and news. However, today, "Media content functions as a tool for the psychological satisfaction of individuals; it entertains its audience, and media use ranks as the dominant free time activity. This is because media content can be consumed individually or as a group, and it provides satisfaction in both cases.” (Işık et al., 2007, p. 44). The reason television is a popular form of entertainment is the colorful world it provides to children, the limited space for outdoor play in cities, the attitudes of the family relating to television and a general inability to make children pursue different out-of-school activities.

That students also develop negative metaphors may be interpreted as highlighting harmful aspects of television and that they are aware of the negative effects of television. For example, the students mentioned the dangers to the health of a child watching television, both through radiation and an excessive addiction to television. "Television has effects with regard to creating a consumerist society, the formation of sexual identity and the conception of the opposite sex, the parent-child relationship, a propensity to violence, reading, thinking, success, cultural alienation and the corruption of language, the formation of self-identity and the raising of children." (Büyükbaykal, 2007). It may be said that the fact that students developed both positive and negative attitudes towards television shows that they are aware of its many roles.

In this study, which analyzed the pictures drawn by the primary school students in accordance with the "iconic, index, symbol" triplet in the semiological scheme of Peirce, the use of semiological analyses contributed to obtaining effective results and in following the mental processes of students by making clear how they perceive and give meaning to the world. In the study, some students drew a family environment relating to television, while some students drew an environment lacking television and/or a desired environment (nature, forest, garden, etc.). These drawings clearly demonstrate the perceptions of the students relating to television. The results of a number of studies conducted on children's pictures (Akalın, 2008; Dülger, 2008; Türkkan, 2004) indicate these pictures reflect their inner worlds, and this is supported by the results of the study. Moreover, this study also enables the psychological and mental processes of a student to be followed thanks to semiological analyses. It was concluded that the objects drawn in this study were predominantly 'icons', then 'symbols' and, finally, 'indices'. The most commonly used icons were the television at home and furniture around the television and objects on TV with entertaining elements. It is also a fact that the students drew other objects from their imagination that they wished to be present. Examining the explanations of the pictures they drew, the reason for using a number of images may be that in their domestic environments they perceive the television and living and non-living objects around the television as a whole. Also, on examination of the pictures, it was seen that almost all children tried to draw themselves or their peers as children watching television. The reason for this may be the self-centeredness of children of this age. In addition, the students drew pictures within the TV (police vehicles, cars, newsreaders, rope, sword, written news, etc.) and TV brands and channels as iconic signs. This may be 
interpreted as showing a need to include details and to reflect their domestic environments as affected by iconic components such as daily-watched news, movies, commercials, etc. When the students were asked to write down reasons for drawing the pictures, it was seen that they had tried to reflect their own situations while watching television. Symbols and images drawn by the primary school students relating to television generally evoked happiness. In addition, it was possible to see success, excitement, joy and other emotions as well. The most commonly drawn symbol was the smiling-child symbol. We can conclude that each student who drew a smiling child likes and enjoys watching TV. Moreover, the student drawing the TV as a part of the family described it as a person, and showed that she/he regards TV as a part of the family by drawing hands and arms on the television. In the study, the most commonly used sign after the icon was the symbol. Also, when one student's reason for drawing a book was given, it was seen that she/he associated success with books by expressing the idea that television blunts a human being mentally and that we should read books. The main reason for drawing pictures with symbols is that the students want to draw a picture expressing emotions such as happiness, entertainment, excitement evoked in their minds. The least commonly used type of pictures were indices. It was thus seen that the students did not often include any kind of cause-effect relationship in their pictures.

We can conclude that the primary school students are mentally prone to drawing more concrete components due to their ages, and they draw without thinking about any underlying cause-effect relationship. It was concluded from statements of the students regarding their pictures that they had perceptions of television including entertainment/happiness, provision of information and news, damage to the eyes, pleasure in playing games, the emission of radiation, television as part of family, advertisements, enabling of imagination, damage to the brain, awareness of natural beauty, benefits and harm, disrupting of work, wasting time, triggering violence, having a negative impact on success and disrupting of mental and physical health. These can be interpreted as showing the awareness of the participants of both the good and bad aspects of television. In a study conducted by Özkan (2014), it was concluded that there was at least one television in the participants' houses, that most children watched television for 2 or more hours a day, the proportion of health problems experienced by children watching more than 2 hours television a day $(69.3 \%)$ was higher than those watching television for one hour a day (36\%), and children experienced problems with eye health and sleeping. In a study conducted by İşleyen and İşleyen (2015), it was found that the media were used for collecting data and receiving information, while some children also consumed media content to pass the time and for entertainment. In their research on children and television, Glenn, Knight, Holt and Spence (2013) contrast play and television, with the latter sometimes being seen as a very boring activity. The results of Özkan (2014) and İşleyen and İşleyens' (2015) studies are similar to the results of this study. Examining the perceptions and opinions of participants of this age without any education about the media, it can be said that their awareness and ability to analyze concepts are nevertheless advanced. However, with education about television and other media, and an increased parental awareness of this issue, a greater consciousness of the need to protect themselves from the negative aspects of the media will develop.

It is necessary that parents consciously teach their children to watch television responsibly and that they enable their children to avoid any possible negative situations. For this purpose, parents should limit the time spent watching television, the television should be switched off after certain hours and specific programs, program content should be monitored, television should not be regarded as a babysitter, children should not be left alone in front of the television, it should not turn into the main way of spending free time, and food should not be eaten while watching it. In addition, it should be noted that the authorities and those who run television channels have an important duty to act responsibly. They should make and broadcast programs that provide the right messages to children.

This study aimed to determine the perceptions of children by means of the metaphors they use and pictures they draw, and it can be considered as a starting point for future studies. In the future, other studies may be conducted using various techniques such as drawings, interviews, focus group interviews, etc. relating to other forms of mass communication and media. In addition, studies could be conducted on the purposes of different types of media, and how the media affects people. This study was conducted with $3^{\text {rd }}$ and $4^{\text {th }}$ grade primary school students; similar studies could be conducted with different age groups and categories using different methods.

\section{References}

Akalın, T. (2008). The reflection of family life in the pictures of primary school second class student (Unpublished master's thesis). Gazi University, Ankara, Turkey.

Aksaçlığlu, A. G., \& Yılmaz, B. (2007). Impacts of Watching Television and Computer Using on Students' Reading Habits. Turkish Librarianship, 21(1), 3-28 Retrieved from http://tk.org.tr/index.php/TK/article/viewFile/8/8

Aral, N., \& Aktaş, Y. (1997). Examination of time spent on television and other activities by children. Hacettepe University Journal of Faculty of Education. 13, 99-105 Retrieved from

http://www.efdergi.hacettepe.edu.tr/yonetim/içerik/makaleler/1186-published.pdf 
Arslan, M. M., \& Bayrakçı, M. (2006). An examinatıon of metaphorical thinking and learning from educational view. Journal of National Education, 171, 100-108 Retrieved from http://dhgm.meb.gov.tr/yayimlar/dergiler/Milli_Egitim_Dergisi/171/index3-icindekiler.htm

Barr, R., Lauricella, A., Zack, E., \& Calvert, S. L. (2010). Infant and early childhood exposure to adult-directed and child-directed television programming: Relations with cognitive skills at age four. Merrill-Palmer Quarterly, 56(1), 21-48. https://doi.org/10.1353/mpq.0.0038

Berk, L. E. (2013). Physical development in middle childhood Infants and children. (N. I. Erdoğan Trans. Ed. E. F. Bedel Sec. trans. From prenatal to middle childhood p.463), Ankara: Nobel Press

Bland, D. (2012). Analyzing children's drawings: applied imagination. International Journal of Research and Method in Education, 35(3), 235-242. https://doi.org/10.1080/1743727X.2012.717432

Boz, H. A. (1999). Mass communication tools and silence helix, Ankara University Journal of Faculty of Education Sciences, 32(1), 42-48 Retrieved from http://dergiler.ankara.edu.tr/detail.php?id=40\&sayi_id=127

Büyükbaykal, G. (2007). Effects of television on children. Journal of Faculty of Communication, 28, 31-44 Retrieved from http://www.journals.istanbul.edu.tr/iuifd/article/view/1019010386/1019009624

Carlson, L., Laczaniak, R. N., \& Walsh, A. (2001) Socializing children about television: An intergenerational study. Journal of the Academy of Marketing Science, 29(3), 276-288. https://doi.org/10.1007/BF02890785

Catron, C. E., \& Allen, J. (2008). Early Childhood Curriculum: A Creative Play Model. New Jersey: Pearson Education

Chang, N. (2000). Reasoning with Children about violent television shows and related toys. Early Childhood Education Journal, 28(2), 85-89. https://doi.org/10.1023/A:1009595219927

Christakis, D. A., Garrison, M. M., Herrenkohl, T., Haggerty, K., Rivara, F. P., Zhou, C., \& Liekweg, K. (2013). Modifying Media Content for Preschool Children: A Randomized Controlled Trial. The American Academy of Pediatrics, 131(3), 431-438. https://doi.org/10.1542/peds.2012-1493

Coşgun, M. (2012). Effect of television series on identity development of young people and socialization process (Sakarya Province Sample). Journal of Academic View, 28, 1-21 Retrieved from http://www.akademikbakis.org/eskisite /28/16.pdf

Dağlıoğlu, H. E. (2014). Evaluation of human figure drawings of 5-7 age group children in terms of development. International Online Journal of Educational Sciences, 6(2), 510-523. https://doi.org/10.15345/iojes.2014.02.020

Demir, M.K., \& Ülkü, E. Ç. (2013). Effect of mass communication tools on in-class behaviors of students. International Journal of Social Science, 6(1), 587-608. Retrieved from https://www.jasstudies.com/Makaleler /1777674437_Demirmehmetkaan-el\%C3\%A7in_S-587-608.pdf

Dervişcemaloğlu, B. (2005). Göstergebilim. Retrieved from http://www.ege-edebiyat.org/docs/493.pdf

Dülger, N. (2008). Reflection of familial and individual characteristics of 06-11 age students in pictures (Unpublished master's thesis), Süleyman Demirel University, Isparta, Turkey.

Eraslan, L. (2011). Sociological metaphors. International Refereed E-Journal of Social Sciences, 28, 1-22 Retrieved from http://bingol.edu.tr/media/208383/sosyolojik-dusunme-bolum9-Sosyolojik- metaphors.pdf

Erdoğan, F., Uysal, H, T., Altin, A., \& Saki, E. (2015). Association of concepts of tendency to television, identification and media literacy: a research on children in adolescence period. The Journal of International Social Research 8(39) 846-860. https://doi.org/10.17719/jisr.20153913801

Erdogan, T., \& Erdoğan, Ö. (2013). A metaphor analysis of the fifth-grade students' perception about writing. Asia Pacific Edu Res. 22(4), 347-355. https://doi.org/10.1007/s40299-012-0014-4

Ergen, B., \& Yanpar, Y. T. (2015) Metaphorical perceptions of primary school $3^{\text {rd }}$ grade students on technology concept. The Journal of Academic Social Science Studies, 39, 509-527. https://doi.org/10.9761/JASSS2975

Erişti, S. D. (2010). Popular Culture Perceptions of Primary School Students in Picture Expressions (Norway Multicultural Fjell Primary School Sample)). Primary School Online, 9(3), 884-897 Retrieved from http://dergipark.gov.tr/download/article-file/90721

Ersoy, A., \& Türkkan, B. (2009). Perceptions about Internet in elementary school children's drawings. Elementary Education Online, 8(1), 57-73. Retrieved from http://ilkogretim-online.org.tr/index.php/io/article/view/1686/1522

Glenn, N. M., Knight, C. J., Holt, N. L., \& Spence, J. C. (2013). Meanings of play among children. Childhood, 20(2), 185-199. https://doi.org/10.1177/0907568212454751 
Goldstein, L. B. (2005). Becoming a teacher as a hero's journey: using metaphor in preservice teacher education. Teacher Education Quarterly, 32(1), 7-24. Retrieved from https://eric.ed.gov/?id=EJ795299

Güler, G., Akgün, L., Öçal, M. F., \& Doruk, M. (2012). Metaphors Possessed by mathematics teacher candidates on mathematics concept. Journal of Research in Education and Teaching, 1(2), 25-29. Retrieved from http://jret.org/FileUpload/ks281142/File/03.guler.pdf

Gündüz, K. Ö. (2010). Media literacy and pre-school children: A research of media literacy awareness. Istanbul University Faculty of Communication Journal, 1(39), 59-73

$\mathrm{http}: / /$ www.acarindex.com/dosyalar/makale/acarindex-1423905512.pdf

Gunter, B., \& McAleer, J. (1997). Children and television. (2 $2^{\text {nd }}$ ed.). London and New York: Routledge. Retrieved from https://eclass.uoa.gr/modules/document/file.php/MEDIA165/media\%20effects- $\%$ CF\%84\%CF\%83\%CE\%B1\%CE \%BB\%CE\%AF\%CE\%BA\%CE\%B7/\%5Bbook\%5Dchildren\%20and\%20tv.pdf

Guru, B. P. M. C., Nabi, C., \& Raslana, R. (2013). Role of Television in Child Development. Mass Communication and Journalism, 3(3), 1-5. Retrieved from https://www.omicsgroup.org/journals/role-of-television-in-child-development-2165-7912.1000153.pdf

Hestroni, A. (2011). Violence in Television Advertising: Content Analysis and Audience Attitudes, Journal Atlantic Journal of Communication, 19(2), 97-112. https://doi.org/ 10.1080/15456870.2011.561170

Hobbs, R. (1998). The seven great debates in the media literacy movement. Journal of Communication, 48(1), 16-32. https://doi.org/10.1111/j.1460-2466.1998.tb02734.x

İnam, Ö. (2008). Metaphor use in television commercials (Unpublished doctoral dissertation). Anadolu University, Eskişehir, Turkey.

Işık, M., Erdem, A., Güllüoğlu, Ö., \& Akbaba, E. (2007). Television and child: An evaluation on television-watching habits of 6-12 aged children. Konya: Hiperlink.

Istomin, K. V., Panakova, J., \& Heady, P. (2014). Culture, Perception, and Artistic Visualization: A Comparative Study of Children's Drawings in Three Siberian Cultural Groups. Cognitive Science, 38, 76-100. https://doi.org/10.1111/cogs.12051

Jusoff, K., \& Sahimi, N. N. (2009). Television and media literacy in young children: Issues and effects in early childhood. International Education Studies, 2(3) 151-157. https://doi.org/10.5539/ies.v2n3p151

Karaçanta, H. (2013). University students' conceptual metaphors about national value. Gazi University Journal of Faculty of Education of Industrial Arts 32, 107-114. Retrieved from http:/dergipark.ulakbim.gov.tr/esef/article/viewFile/5000091865/5000085304

Kaya, K., \& Tuna, M. (2008). Impact of Television on the Socialization of the Children in Primary Education Age. SD Faculty of Science-Education Journal of Social Sciences, 17, 159-182. Retrieved from http://sdu.dergipark.gov.tr/download/article-file/118016

Kayacan, K. İ., \& Eren, N. (2015). The Pictures Which Children Drew Are Their Mirrors! Journal of Psychiatric Nursing, 6(3), 137-142. https://doi.org/10.5505/phd.2015.85547

Krefting, L. (1991). Rigor in qualitative research: The assessment of trustworthiness. The American Journal of Occupational Theraphy, 45(3), 214-222. https://doi.org/10.5014/ajot.45.3.214

Küçükbasmac1, G. (2013). Sellers of words in electronic age: Radio and television. Turkish Studies, 8(4), 1063-1080, Retrieved from

http://www.Turkishstudies.net/Makaleler/1498495548_60K\%C3\%BC\%C3\%A7\%C3\%BCkbasmac\%C4\%B1G\%C 3\%BClten-edb-1063-1080.pdf

Lakoff, G., \& Johnson, M. (2010). Metaphors, Life, Meaning and Language. (Y. D Gökhan, Trans). İstanbul: Paradigma Press. https://doi.org/10.1023/A:1022396729398

Larson, M. S. (2003). Gender, race, and aggression in television commercials that feature children. Sex Roles, 48(1), 67-75. https://doi.org/10.1023/A:1022396729398

Lillard, A. S., \& Peterson, J. (2011). The immediate impact of different types of television on young children's executive function. Pediatrics, 128(4), 644-649. https://doi.org/10.1542/peds.2010-1919

Miles, M. B., \& Huberman, A. M. (1994). Qualitative Data Analysis. ( ${ }^{\text {nd }}$ ed.). Thousand Oaks, CA: Sage Publications.

Mizruchi, S. (2010). Risk theory and the contemporary american novel. American Literary History, 22(1), 109-135. https://doi.org/10.1093/alh/ajp053 
Mutlu, E. (1997). Television, children and violence. Istanbul University Faculty of Communication Journal, 4. 41-77. Retrieved from http:/ / www. journals. istanbul. edu.tr /iuif d/ article /view/ 1019015598/1019014781

Özkan, H. (2014). Determination of attitudes and behaviors of mothers relating to effects of television-watching on 1-6 aged child health (Unpublished master's thesis). Atatürk University, Erzurum, Turkey

Özmakas, U. (2009) Indication Concept in Charles Sanders Peırce. Uşak University Journal of Social Sciences, 2(1), 32-45 Retrieved from http://dergipark.ulakbim.gov.tr/usaksosbil/article/viewFile/5000035962/5000034884

Patton, M. Q. (1987). How to use qualitative methods in evaluation. Newbury Park, CA: Sage.

Pine, K. J., \& Nash, A. (2002). Dear Santa: The effects of television advertising on young children. International Journal of Behavioral Development, 26(6), 529-539. https://doi.org/10.1080/01650250143000481

Rayt, H., Komulainen, K., Paajanen, T., Markkanen, M., Skorokhodova, N., \& Kolesnikov, V. (2012). Portraying intelligence: children's drawing of intelligent men and women in Finnish and Russian Karelia. Education Studies, 38(5), 573-583. https://doi.org/10.1080/03055698.2012.661928

Robinson, L. J., Winiewicz, D. D., Fuerch, J. H., Roemmich, J. N., \& Epstein, L. H. (2006). Relationship between parental estimate and an objective measure of child television watching. International Journal of Behavioral, 3(43), 1-5. https://doi.org/10.1186/1479-5868-3-43

Saban, A. (2004). Metaphors suggested by beginner level class teachers relating to "teacher" concept. Journal of Turkish Education Sciences, 2(2), 131-155. Retrieved from http://www.tebd.gazi.edu.tr/index.php/tebd/article/view File /203/189

Sadık, F., Çakan, H., \& Artut, K. (2011). Analysis of Environment Problems Reflection on Child Pictures in accordance with Socio-economical Differences. Primary school Online 10(3), 1066-1080. Retrieved from http://dergipark.gov.tr/download/article-file/90635

Santrock, J. W. (2011). Development Psychology. (A. E. Aslan, Trans. ed. G. Yüksel Section Translation, Lifelong development. p.303) Ankara: Nobel Press

Savaş, İ. (2014). Child picture and subconscious. (Unpublished master's thesis). İstanbul Arel University, İstanbul, Turkey

Schirrmacher, R. (2001). Art and Creative Development for Young Children. USA: Delmar Learning

Şentürk, R. (2009). Television Theory of Mc Luhan, İstanbul Ticaret University Journal of Social Sciences, 8(15), 17-31. Retrieved from http://www.ticaret.edu.tr/uploads/kutuphane/dergi/s15/17-31.pdf

Simon, L., \& Stokes, P. D. (2015). Sources of Variability in Children's Drawings. Creativity Research Journal, 27(1), 31-38. https://doi.org/10.1080/10400419.2015.992669

Simşek İşleyen, F., \& İşleyen, M. (2015). Analysis of media perception of children over pictures. Global Media Journal, 5(10), 271-287 Retrieved from http://globalmediajournaltr.yeditepe.edu.tr/makaleler/GMJ_10._sayi_bahar_2015/pdf/11-simsekIsliyenIsliyen. Pdf

Singh, K. (2010). Metaphor as a tool in educational leadership classrooms. Management in Education, 24(3), 127-131. https://doi.org/10.1177/0892020608090411

Squires, C. R. (2012). Coloring in the bubble: Perspectives from black-oriented media on the (latest) economic disaster. American Quarterly, 64(3), 543-570. https://doi.org/10.1353/aq.2012.0034

Szukala, A. (2011). Metaphors as a tool for diagnosing beliefs about teaching and learning in social studies teacher education. Journal of Social Science Education, 10(3) 53-73. Retrieved from http://www.jsse.org/index.php/jsse/article/view/1176/1079

Television is watched mercilessly in Turkey (2015, January 6). Medya akademi. Retrieved from http://www.medyaakademi.org/2015/01/06/turkiyede-hunharca-televizyon-izleniyor/

Treske, G. (2011). Why Media Literacy Is Necessary. (N. Türkoğlu., M. C. Şimşek, .Trans.) İstanbul: Parşomen Publishing

TRTC (2013). Media Using Habits of Children in Turkey. Retrieved from http://www.rtuk.org.tr/Home/SolMenu/89

Türkcan, B. (2013). Semiotic Approach to the analysis of children's drawings. Educational Sciences: Theory \& Practice 13(1), 585-607. Retrieved from http://www.kuyeb.com/pdf/tr/511c2942df50a5c51e92bd1abae 4ffc085607.pdf

Turkey broke the world record in television watching (2017, April 04). Milliyet. Retrieved from http://www.milliyet.com.tr/turkiye-televizyon-izlemede-dunya-teknoloji-haber-2426319/ 
Uras, G. (2016, November 12). The book market is a market of $\$ 2.2$ billion. Retrieved from http://www.milliyet.com.tr/yazarlar/gungor-uras/kitap-pazari-2-2-milyar-dolarlik-bir-pazar-2344030/

Wang, T. W. (2014). Children's drawings from China and the United States and conceptions of female beauty. International Journal of Education through Art, 10(3), 363-379. https://doi.org/10.1386/eta.10.3.363_1

Wimmer, M. (2014). Interpreting children's drawings as windows into the inner world of children. Retrieved from http://www.roshida.com/wp-content/uploads/2014/03/12-Must-Know-Facts-about-Childrens-Drawing-Interpretati on.pdf

Yapıc1, Ş. (2006) Television as an education tool and its effects. University and Society, 6(2), 1-15. Retrieved from http://www.universite-toplum.org/text.php3?id=27

Yavuzer, H. (2012). Child psychology. (34 $4^{\text {th }}$ ed.). İstanbul: Remzi Press

Yllmaz, M., \& Temizkan, M. (2013). Semiotical analysis of the published banknotes in the history of the Turkish. Communication Theory and Research Journal Republic, 36, 86-131. Retrieved from http://iletisimdergisi.gazi.edu.tr/site/index.php/IKAD/article/view/49/35

Yurtal, F., \& Artut, K. (2008). The Reflections of Children's Perception of Violence on Their Drawings. Turkish Journal of Child and Adolescent Mental Health, 15, 149-155. Retrieved from http://www.ejmanager.com/mnstemps/46/46-1360737089.pdf?t=1432757796

\section{Copyrights}

Copyright for this article is retained by the author(s), with first publication rights granted to the journal.

This is an open-access article distributed under the terms and conditions of the Creative Commons Attribution license which permits unrestricted use, distribution, and reproduction in any medium, provided the original work is properly cited. 